\title{
BIOPSYCHOSOCIAL FACTORS ASSOCIATED WITH CHILD GROWTH AT NGEMBAL KULON COMMUNITY HEALTH CENTER, KUDUS
}

\author{
Th. Catur Wulan Setyaningrum ${ }^{1,2)}$, Bhisma Murti²), Dono Indarto3) \\ 1)Academy of Midwifery Mardi Rahayu, Kudus \\ 2)Masters Program in Public Health, Sebelas Maret University \\ 3)Faculty of Medicine, Sebelas Maret University
}

\begin{abstract}
Background: The first five years of life is widely acknowledged as a sensitive period for child growth. Any interruption exposing during this period may cause problems in child growth. Various internal and external factors can affect child growth. This study aimed to analyze the effects of biopsychosocial factors associated with child growth with life course perspective.

Subjects and Method: This was an observational analytic study with crosssectional design. It was conducted at Ngembal Kulon community health center, Kudus, Central Java, from December 2016 to February 2017. A total sample of 160 children aged 1 to 5 years old and their mothers were selected for this study by purposive sampling. The dependent variable was child growth as measured by weight for age (WAZ) and height for age (HAZ). The independent variables were birth weight, body length at birth, maternal height, number of children, and family income. The data was collected by a set of questionnaire. Child and maternal heights were measured by microtoise. Data on birthweight and body length at birth were obtained from maternal and child health book. Multiple linear regression was used for data analysis.

Results: Child growth (WAZ) was associated with family income (b=0.36; $95 \% \mathrm{CI}=0.22$ to $0.49 ; \mathrm{p}<0.001)$, birthweight $(\mathrm{b}=0.42 ; 95 \% \mathrm{CI}=0.25$ to 0.58 ; $\mathrm{p}<0.001)$, and number of children $(\mathrm{b}=-0.25 ; 95 \% \mathrm{CI}=-0.42$ to $-0.08 ; \mathrm{p}=$ 0.004). Child growth (HAZ) was associated with family income $(b=0.26 ; 95 \%$ $\mathrm{CI}=0.12$ to $0.39 ; \mathrm{p}<0.001)$, body length at birth $(\mathrm{b}=0.21 ; 95 \% \mathrm{CI}=0.12$ to $0.30 ; \mathrm{p}<0.001)$, and maternal height $(\mathrm{b}=0.43 ; 95 \% \mathrm{CI}=0.27$ to 0.58 ; $\mathrm{p}<0.001)$.

Conclusion: Child growth (WAZ) is associated with family income, birthweight, and number of children. Child growth (HAZ) is associated with family income, body length at birth, and maternal height. Life course influences were demonstrated in this study.
\end{abstract}

Keywords: child growth, WAZ, HAZ, birthweight, body length at birth, number of children, maternal height, family income

Correspondence: Th. Catur Wulan Setyaningrum. Academy of Midwifery Mardi Rahayu, Kudus. Email: theresia.akmr@yahoo.com.

Mobile: +6285641897987. 